CASE REPORTS

\title{
Hypocalcaemic response to streptomycin in malignant hypercalcaemia
}

\author{
W. E. W. RoEdIGER \\ M.B.B.Ch.
}

D. LUDWIN

M.B.B.Ch.

\author{
R. A. HINDER \\ F.R.C.S. \\ Department of Surgery, University of the Witwatersrand and The Johannesburg \\ General Hospital, Johannesburg, South Africa
}

\begin{abstract}
Summary
We report a case of malignant hypercalcaemia associated with primary hepato-cellular carcinoma in whom streptomycin produced a notable and reproducible fall in serum calcium. A hypocalcaemic response to streptomycin has been reported from experimental animals but not previously from man.
\end{abstract}

\section{Introduction}

Malignant hypercalcaemia (pseudohyperparathyroidism) is occasionally associated with primary hepatocellular carcinoma (PHC) or cholangio carcinoma which has not metastasized to bone (Becker, Sternberg and Kalser, 1963; Keller, Goldschneider and Lafferty, 1965; Knill-Jones et al., 1970). Normocalcaemia is restored if the tumour is resected or a liver transplant undertaken (Knill-Jones et al., 1970). Generally, treatment of PHC with radiotherapy or chemotherapy has met with little success and the prognosis remains poor (El-Domeiri et al., 1971; Falkson, 1973). In the case reported here, the primary liver cancer was irresectable. The hypercalcaemia proved refractory to treatment with oral phosphates, glucagon and saline infusions, but responded transiently to intra-arterial mitomycin-C and markedly to parenteral streptomycin. The hypocalcaemic effect of streptomycin has been reported from experimental animals (Galante et al., 1970), but not previously from patients with hypercalcaemia.

\section{Case report}

A 45-year-old male patient presented in January 1973 with dyspepsia, polyuria, polydipsia and marked weight loss, all of which had been present for 6 months. He was moderately emaciated with slight epigastric tenderness and a one finger smooth hepato- megaly. A bruit was heard over the right lobe of the liver. The remainder of the examination was unremarkable.

Investigations in January 1973 were: haemoglobin $15.2 \mathrm{~g} / 100 \mathrm{ml}$; ESR (Westergren) $30 \mathrm{~mm}$ in the first hour; bilirubin (total) $0.8 \mathrm{mg} / 100 \mathrm{ml}$; alkaline phosphatase 36.6 and $30 \cdot 1$ K.A. units; 5 -nucleotidase 21.6 units (normal 2-17); serum calcium $7 \cdot 2 \mathrm{mEq} / 1$ and $7.0 \mathrm{mEq} / \mathrm{l}$; serum phosphorus $2.2 \mathrm{mg} / 100 \mathrm{ml}$ and 1.5 $\mathrm{mg} / 100 \mathrm{ml}$; ionized serum calcium $3.2 \mathrm{mEq} / \mathrm{l}$; serum albumin $2.96 \mathrm{~g} / 100 \mathrm{ml} ; \gamma$-globulin $2.51 \mathrm{~g} / 100$ $\mathrm{ml}$; serum electrolytes: urea $38 \mathrm{mg} / 100 \mathrm{ml}$, potassium $4.1 \mathrm{mEq} / \mathrm{l}$, sodium $142 \mathrm{mEq} / \mathrm{l}$, chlorides 101 $\mathrm{mEq} / \mathrm{l}$ and carbon dioxide content of $28 \mathrm{mEq} / \mathrm{l}$; blood gas status (Astrup): $\mathrm{pH} 7 \cdot 50, \mathrm{pCo}_{2} 36 \cdot 5$ $\mathrm{mmHg}$, base excess $+4.5 \mathrm{mEq} / \mathrm{l}$ and standard bicarbonate $28.5 \mathrm{mEq} / \mathrm{l}$.

The immunodiffusion test for $\alpha$-fetoprotein was positive and the complement fixation test for hepatitis-B (Australia) antigen was positive in a titre of $1 / 16$.

The phosphate excretion index when the patient was on a routine ward diet was +0.31 (normal +0.09 to -0.09 ); creatinine clearance (24-hr) was $100 \mathrm{ml} / \mathrm{min}$; urinary electrolyte excretion per day (mean of fourteen estimations over 28 days); calcium $225 \mathrm{mEq} / \mathrm{l}(167-374 \mathrm{mEq} / \mathrm{l})$; phosphorus $617 \mathrm{mg} / 100$ $\mathrm{ml}$ (290-1530 mg/100 ml); sodium $31 \mathrm{mEq} / \mathrm{l}(12-76$ $\mathrm{mEq} / \mathrm{l})$; potassium $22 \mathrm{mEq} / \mathrm{l}(8-43 \mathrm{mEq} / \mathrm{l})$; urinary $\mathrm{pH}$ was never below 5.8 and in the short urinary acidification test of Wrong and Davies (1959) the urine $\mathrm{pH}$ fell to 5.40 at $4 \mathrm{hr}$ and 5.55 at $10 \mathrm{hr}$. A $50 \mathrm{~g}$ oral glucose tolerance test and D-xylose absorption test was normal.

Liver scan with ${ }^{99 \mathrm{~m}} \mathrm{Tc}$ sulphur-colloid revealed two filling defects in the right lobe of the liver in a posterosuperior position. Percutaneous biopsy of these areas 
showed features of a hepatocellular carcinoma with loss of normal architecture. Radiographic skeletal surveys were repeated at monthly intervals (January, February, March) and these did not indicate features of bony metastases or signs of primary hyperparathyroidism. A bone scan was not performed. Two coin lesions, each $1 \mathrm{~cm}$ in diameter, were noted in the left lower lobe of the lung. Excision biopsy of these was performed on 15 January 1973 through a left thoracotomy incision. Histology was consistent with metastases from a PHC.

\section{Treatment}

As the tumour was not amenable to resection, control of the hypercalcaemia was attempted. Neutral phosphates, $3 \mathrm{~g} /$ day, produced no significant decrease in serum calcium levels. Saline infusion $(300 \mathrm{mEq} /$ day $)$ produced a marked calcium diuresis with a return to normal of the metabolic alkalosis. However, it failed to lower the high serum calcium levels. Glucagon $(1.0 \mathrm{mg}$ three times per day, given as parenteral injection) did not affect serum calcium levels. Steroids were withheld until resectability of the tumour was assessed by means of biopsies, but were then not given as a hypocalcaemic response to streptomycin was observed. Following two short courses of penicillin and streptomycin for respiratory infection, a marked fall in serum calcium was noted (14 January 1973-18 January 1973 calcium fell from $6.6 \mathrm{mEq} / 1$ to $5.6 \mathrm{mEq} / \mathrm{l}$, and 24 January $1973-27$ January 1973 from $6.0 \mathrm{mEq} / 1$ to $4.9 \mathrm{mEq} / \mathrm{l}$ ) with a marked rise $48 \mathrm{hr}$ after the streptomycin was stopped. Treatment with streptomycin was repeated during February and March (Fig. 1). Treatment with saline infusions was also used. Each course of streptomycin produced a prompt reduction of serum calcium and a slow, significant decrease in serum alkaline phosphatase. Isoenzyme estimation by starch-gel electrophoresis (Taswell and Jeffers, 1963) showed a predominant decrease in the bone isoenzyme during streptomycin treatment. No alteration in creatinine clearance or urinary electrolyte excretion was noted on this regime, nor was the metabolic alkalosis corrected unless saline infusion was added to the treatment.

In view of this response to streptomycin, coeliac artery perfusion with mitomycin-C, a Streptomycesderived cytotoxin, was performed according to the method of Yamada et al. (1970). A total dose of 120 $\mathrm{mg}$ was given. Addition of this chemotherapeutic agent to the treatment led to a transient fall in serum calcium and alkaline phosphatase levels which returned to normal within 4 days. No radiological shrinkage of the tumour was observed with mitomycin-C. At this point the patient requested to be

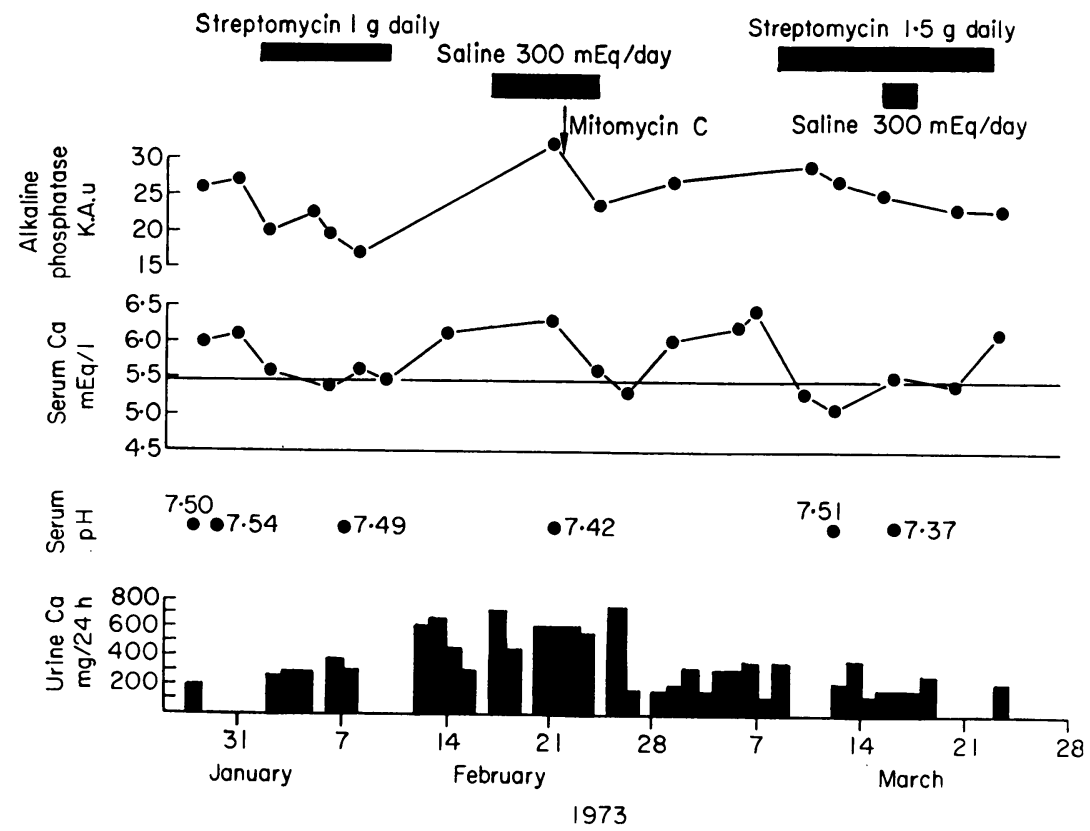

FIG. 1. The effect of streptomycin, daily saline infusions and mitomycin-C on hypercalcaemia. Serum calcium and alkaline phosphatase fell during streptomycin and mitomycin therapy. Saline infusions corrected the metabolic alkalosis. 
allowed to return to his rural home and was lost to follow-up.

\section{Discussion}

The mechanism of hypercalcaemia in PHC is unknown. One reported case of cholangiocarcinoma with hypercalcaemia had elevated immuno-reactive parathyroid hormone levels (Knill-Jones et al., 1970). Such ectopic parathormone production is known in many other tumours which produce the syndrome of pseudohyperparathyroidism. That this case is one of pseudohyperparathyroidism is indirectly adducible from the following features: the high initial serum calcium levels (Lafferty, 1966), a marked metabolic alkalosis (Heineman, 1965) which is not attributable to vomiting, diarrhoea or gross electrolyte loss, rapid weight loss, absence of renal calculus disease and failure to demonstrate radiographic signs of primary hyperparathyroidism. Bony metastases are extremely rare in PHC (Moseley, 1967) and were not observed in this patient. The presence of microscopic bone deposits could not be verified.

The hypocalcaemic action of the Streptomycesderived antibiotics has recently been reported by Galante et al. (1970) who showed that streptomycin and other amino-glycosides produce a dose-related fall of serum calcium in rats. Clinically a similar response is noted in the present case of pseudohyperparathyroidism. The hypocalcaemic effect in animals is abolished in euparathyroid-thyroidectomized animals and was related to a rise in plasma calcitonin levels. Calcitonin levels were not measured in this patient and production of hypocalcaemia by action of this hormone was not established.

Glucagon, a hypocalcaemic agent in man (Birge and Avioli, 1969) and a calcitonin-releasing agent in medullary carcinoma of the thyroid (Melvin, Voelkel and Tashjian, 1970), did not produce any fall in serum calcium in the present case. It is now known that glucagon does not stimulate calcitonin-release in normal subjects, i.e. those without medullary carcinoma (Tashjian et al., 1970), an observation which is reflected in the present patient as he did not show a calcitonin-like response to glucagon.

The Streptomyces-derived cytotoxic, mithramycin (S. plicatus), produces short lived hypocalcaemia with single dose injections in malignant hypercalcaemia (Slayton et al., 1971). The present case shows that another Streptomyces-derived cytotoxin, mitomycin-C ( $S$. caespitosus), produces a temporary fall in serum calcium not unlike the response noted with mithramycin. Mithramycin and mitomycin are structurally unrelated; however, Galante et al. (1970) point out that the hypocalcaemic effect of the aminoglycosides is unrelated to their structure and from the present case this seems to apply to the cytotoxic derivatives of this group.
Further investigation of the relationship between streptomycin and serum calcium is needed in order to establish the role of this aminoglycoside in human calcium turnover.

\section{Acknowledgments}

The authors would like to thank the Superintendent, Johannesburg General Hospital, for permission to publish this case and Dr Ipp for undertaking the alkaline phosphatase isoenzyme estimations.

\section{References}

Becker, D.J., Sternberg, M.S. \& Kalser, M.H. (1963) Hepatoma associated with hypoglycemia, polycythemia and hypercalcemia. Journal of the American Medical Association, 186, 1018.

BIRGE, S.J. \& Avioli, L.V. (1969) Glucagon-induced hypocalcemia in man. Journal of Clinical Endocrinology and Metabolism, 29, 213.

El-Domeiri, A.A., Huvos, A.G., Goldsmith, H.S. \& Foote, F.W. (1971) Primary malignant tumors of the liver. Cancer, $27,7$.

FALKSON, G. (1973) Chemotherapy of primary liver cancer in the Bantu. In: Liver (Ed. by S. J. Saunders and J. Terblanche), p. 313. Pitman, London.

Galante, L., Horton, R., Wiggins, R.C., Gudmundsson, T.V. \& MACINTYRE, I. (1970) Calcitonin-like action of streptomycin. In: Calcitonin 1969, Proceedings of the Second International Symposium, p. 427. Heinemann, London.

Heineman, H.O. (1965) Metabolic alkalosis in patients with hypercalcemia. Metabolism, 14, 1137.

KELleR, R.T., GoldSChNeIDER, I. \& LAFFERTY, F.W. (1965) Hypercalcemia secondary to a primary hepatoma. Journal of the American Medical Association, 192, 782.

Knill-Jones, R.P., Buckle, R.M., Parsons, V., Calne, R.Y. \& Williams, R. (1970) Hypercalcemia and increased parathyroid-hormone activity in primary hepatoma. New England Journal of Medicine, 282, 704.

LAFFERTY, F.W. (1966) Pseudohyperparathyroidism. Medicine (Baltimore), 45, 247.

Melvin, K.E.W., Voelkel, E.P. \& Tashuian, A.H. (1970) Medullary carcinoma of the thyroid: stimulation by calcium and glucagon of calcitonin secretion. In: Calcitonin 1969. Proceedings of the Second International Symposium, p. 487. Heinemann, London.

Moseley, R.V. (1967) Primary malignant tumors of the liver: a review of the clinical and pathologic characteristics of 47 cases and a discussion of current diagnostic techniques and surgical management. Surgery, 61, 674.

Slayton, R.E., Shnider, B.I., Elias, E., Horton, J. \& Perlia, C.P. (1971) New approach to the treatment of hypercalcemia. The effect of short-term treatment with mithramycin. Clinical Pharmacology and Therapeutics, 12, 833.

Tashian, A.H., Howland, B.G., Kenneth, B.A., Melvin, E.W. \& STRATton Hill, C. (1970) Immunoassay of human calcitonin in normal and disease states. New England Journal of Medicine, 283, 890.

TASWELL, H.F. \& JEFFERS, D.M. (1963) Isoenzymes of serum alkaline phosphatase in hepatobiliary and skeletal disease. American Journal of Clinical Pathology, 40, 349.

WRONG, O. \& DAVIES, H.E.F. (1959) The excretion of acid in renal disease. Quarterly Journal of Medicine, 28, 259.

Yamada, E., Tanaka, Y., Miyaishi, S., Kuroyanagi, Y., KIDO, C. \& KAEKo, M. (1970) One-shot infusion of nonsurgically administered mitomycin-C in the celiac artery for liver metastases. International Surgery, 54, 393. 